\title{
Effect of metformin on the human T98G glioblastoma multiforme cell line
}

\author{
ALİ UCBEK ${ }^{1}$, ZEYNEP GÜNEŞ ÖZÜNAL ${ }^{2}$, ÖZGE UZUN ${ }^{1}$ and AKÇAHAN GEPDİREMEN ${ }^{1}$ \\ ${ }^{1}$ Department of Pharmacology, Faculty of Medicine, Abant Izzet Baysal University, Bolu 14280; \\ ${ }^{2}$ Department of Pharmacology, Istanbul Faculty of Medicine, Istanbul University, \\ Istanbul 34390, Turkey
}

Received September 4, 2013; Accepted February 18, 2014

DOI: $10.3892 / \mathrm{etm} .2014 .1597$

\begin{abstract}
Metformin is a guanidine derivative found in Galega officinalis that is commonly used to treat diabetes mellitus. The mechanism of action of metformin involves regulation of the adenosine monophosphate-activated protein kinase/mammalian target of rapamycin signaling pathway, which is implicated in the control of protein synthesis and cell proliferation. This led to the hypothesis that metformin reduces the risk of cancer and slows tumor growth. Thus, in the present study, the effectiveness of metformin as an antiglioma agent was evaluated using the human $\mathrm{T} 98 \mathrm{G}$ glioblastoma multiforme cell line. The viability of the T98G cells was assessed using a 3-(4,5-dimethylthiazol-2-yl)-2,5-diphenyltetrazolium bromide assay. Apoptosis was monitored by measuring caspase- 3 levels, as well as by terminal deoxynucleotidyl transferase dUTP nick end labeling and staining with acridine orange and ethidium bromide. The results demonstrate that metformin reduced cell viability and caused apoptotic morphological changes in the T98G cells. Furthermore, the caspase-3 levels in the metformin-treated $\mathrm{T} 98 \mathrm{G}$ cells were higher than those in the control cells. Metformin induced apoptosis in the T98G cell line in a concentration-dependent manner. Metformin may provide an important contribution to the treatment of glioblastoma multiforme.
\end{abstract}

\section{Introduction}

Metformin is widely used for the treatment of type II diabetes; it promotes lower blood glucose levels by increasing muscle glucose uptake, decreasing insulin resistance and improving insulin sensitivity. Metformin has been suggested to be useful for the treatment of diseases other than type II diabetes,

Correspondence to: Dr Zeynep Güneş Özünal, Department of Pharmacology, Istanbul Faculty of Medicine, Istanbul University, Turgut Özal street, Istanbul 34390, Turkey

E-mail: zeynepgunes.ozunal@gmail.com

Key words: metformin, T98G, glioblastoma cell line, apoptosis including polycystic ovary syndrome and non-alcoholic fatty liver disease, and for reducing the risk of cardiovascular disease (1). Furthermore, a number of studies have shown that metformin plays a role in reducing the risk of certain central nervous system diseases, specifically Parkinson's and Alzheimer's diseases (2,3). Studies have increasingly focused on the association between metformin and cancer (4) due to data showing that metformin may reduce the risk of cancer in and improve the prognosis of type II diabetes $(5,6)$. The inhibitory effect of metformin on cancer development and tumor growth is not yet clearly understood, but it may be due to the induction of reductions in systemic glucose and insulin levels (4). Conversely, numerous studies have demonstrated that metformin causes apoptosis and may directly inhibit cell proliferation and induce cell death (7-9). These effects of metformin are explained by its activation of the adenosine monophosphate-activated protein kinase (AMPK)-liver kinase B1 (LKB1) signaling pathway, downregulation of cyclin D1 and inhibition of mammalian target of rapamycin (mTOR) activity (10-13).

Glioblastoma multiforme is the most devastating type of cancer of the central nervous system. The median survival time is generally one year from the time of diagnosis. Despite advances, chemotherapeutics have not been successful due to their high toxicity, limited efficacy and problems with drug delivery $(14,15)$. Novel approaches are required for glioblastoma treatment, including chemotherapy, radiotherapy, and the targeting of apoptosis and cell survival regulatory machinery (16). Given the aforementioned characteristics of metformin, it may be a good candidate for the treatment of glioblastoma. Furthermore, metformin crosses the blood-brain barrier when administered orally and exerts a direct effect on the central nervous system (17).

In the present study, based on epidemiological, clinical and preclinical investigations, the effect of metformin on the human T98G glioblastoma multiforme cell line was examined. The viability of the T98G cells was assessed using a 3-(4,5-dimethylthiazol-2-yl)-2,5-diphenyltetrazolium bromide (MTT) assay. Apoptosis was induced by $\mathrm{H}_{2} \mathrm{O}_{2}$ and monitored by measuring caspase- 3 levels, as well as by terminal deoxynucleotidyl transferase dUTP nick end labeling (TUNEL) and acridine orange/ethidium bromide staining. 


\section{Materials and methods}

Cell culture. T98G cells were obtained from Dr Ayhan Bilir, Histology Department, Faculty of Medicine, Istanbul University (Istanbul, Turkey). The T98G glioblastoma cell line was maintained in growth medium [Dulbecco's modified Eagle's medium (DMEM)/F12; Gibco-BRL, Carlsbad, CA, USA]. The medium was supplemented with $10 \%$ fetal bovine serum (FBS; Gibco-BRL) and $1 \%$ antibiotic-antimycotic solution (Gibco-BRL). The cells were incubated in a humidified atmosphere at $37^{\circ} \mathrm{C}$ and $5 \% \mathrm{CO}_{2}$. For cell harvesting, $0.05 \%$ trypsin-ethylenediamine tetraacetic acid (EDTA; Biological Industries, Kibbutz Beit Haemek, Israel) was used. Metformin (Sigma-Aldrich, St. Louis, MO, USA) was used at concentrations of 1, 5, 10, 50 or $100 \mathrm{mM}$ and $\mathrm{H}_{2} \mathrm{O}_{2}$ (Acros Organics, Fair Lawn, NJ, USA) was used at a concentration of $2.5 \mathrm{mM}$ when applied alone or in combination. Consecutive dilutions were prepared with DMEM/F12 medium.

MTT assay. The MTT assay is based on the cleavage of yellow tetrazolium salt MTT to purple formazan crystals by metabolically active cells. The MTT test [Cell Proliferation kit I (MTT); Roche Applied Science, Penzberg, Germany] was used to measure cytotoxicity. The T98G cells were seeded in culture plates at a density of $3 \times 10^{4}$ cells per well in 96-well plates for $24 \mathrm{~h}$. The cells were grown in the 96-well plates in a final volume of $100 \mu \mathrm{l}$ culture medium supplemented with $10 \%$ FBS and $1 \%$ antibiotic-antimycotic solution per well. The cells were incubated for $24 \mathrm{~h}$ to allow cell adhesion. The total volume was then removed, and the cells were treated with metformin $(1,5,10,50$ or $100 \mathrm{mM}), \mathrm{H}_{2} \mathrm{O}_{2}(2.5 \mathrm{mM}), \mathrm{H}_{2} \mathrm{O}_{2}$ and metformin, or culture medium alone and incubated for $24 \mathrm{~h}$. Following the incubation period, $10 \mu \mathrm{l}$ MTT labeling reagent (final concentration, $0.5 \mathrm{mg} / \mathrm{ml}$ ) was added to each well. The 96-well plates were incubated for $4 \mathrm{~h}$. Subsequently, $100 \mu \mathrm{l}$ solubilization solution was added to each well. The 96-well plates were allowed to stand overnight in an incubator in a humidified atmosphere. Complete solubilization of the purple formazan crystals was then assessed. The 96-well plates were subjected to agitation, and the spectrophotometric absorbance of the samples was run using a (ELISA) microplate reader (Thermo Fisher Scientific, Vantaa, Finland) at $570 \mathrm{~nm}$ with a $630-\mathrm{nm}$ reference. The mean absorbance of the control wells served as $100 \%$ viability, and the absorbance of sample wells was calculated from the following equation: Viability $(\%)=$ optical density in the sample well/optical density in the control well x 100 .

Caspase-3 assay. A caspase-3 colorimetric protease assay (ApoTarget $^{\mathrm{TM}}$ Caspase Colorimetric Protease Assay Sampler kit; Novex ${ }^{\circledR}$, Invitrogen Life Technologies, Carlsbad, CA, USA) was performed to detect caspase-3 activity. In this assay, upon cleavage of the substrate by caspase-3, light absorbance by free $p$-nitroanilide (pNA) was quantified using a microplate reader (Thermo Fisher Scientific). The T98G cells were seeded in $25-\mathrm{cm}^{2}$ flasks and incubated for $24 \mathrm{~h}$ at $37^{\circ} \mathrm{C}$ and in $5 \%$ $\mathrm{CO}_{2}$ to allow cell adhesion. The cells were then treated with metformin $(1,5,10,50$ or $100 \mathrm{mM}), \mathrm{H}_{2} \mathrm{O}_{2}(2.5 \mathrm{mM}), \mathrm{H}_{2} \mathrm{O}_{2}$ and metformin, or culture medium alone, and incubated for $24 \mathrm{~h}$. Following the incubation period, the cells were detached and centrifuged to obtain a pellet. The supernatant was removed, and the cells were resuspended in $50 \mu 1$ of chilled cell lysis buffer and incubated on ice for $10 \mathrm{~min}$. The tubes were then centrifuged for $1 \mathrm{~min}$ in a microcentrifuge $(10,000 \mathrm{xg})$. The cytosolic extract was transferred to a fresh tube and put on ice. The protein concentration was assayed using the biuret method (Biuret solution; Norateks Kimya San. Tic. Ltd. Şti., Istanbul, Turkey). Each cytosolic extract was diluted to an equalized protein concentration with cell lysis buffer. Dithiothreitol (DTT; ApoTarget ${ }^{\mathrm{TM}}$ Caspase Colorimetric Protease Assay Sampler kit; Invitrogen Life Technologies) was added to the reaction buffer immediately prior to use. A total of $50 \mu 12 \mathrm{X}$ reaction buffer containing $10 \mathrm{mM}$ DTT was added to each sample. Subsequently, $5 \mu$ l Ac-Asp-Glu-Val-Asp-pNA (DEVD-pNA) substrate was added, and the samples were incubated at $37^{\circ} \mathrm{C}$ for $2 \mathrm{~h}$ in the dark. The absorbance of each sample was read at $405 \mathrm{~nm}$. All samples and controls were run in duplicate. The fold increase in caspase- 3 activity was determined by comparison of the absorbance of pNA from the metformin groups with that from the control group.

Acridine orangelethidium bromide staining. The T98G cells were seeded in 24-well plates and treated with metformin (1, 5, 10,50 or $100 \mathrm{mM}), \mathrm{H}_{2} \mathrm{O}_{2}(2.5 \mathrm{mM}), \mathrm{H}_{2} \mathrm{O}_{2}$ and metformin, or culture medium alone, and then incubated for $24 \mathrm{~h}$. Subsequently, diluted acridine orange $(100 \mu \mathrm{g} / \mathrm{ml}$; Invitrogen Life Technologies) and ethidium bromide $(100 \mu \mathrm{g} / \mathrm{ml}$; Sigma-Aldrich) in phosphate-buffered saline were added to the wells. The samples and controls were incubated in the dark. After $10 \mathrm{~min}$, the wells were examined by fluorescence microscopy (Olympus CKX41, Olympus U-RFLT50-20, Japan).

TUNEL assay. The T98G cells were seeded in 24-well plates and treated with metformin $(1,5,10,50$ or $100 \mathrm{mM}), \mathrm{H}_{2} \mathrm{O}_{2}$ (2.5 mM), $\mathrm{H}_{2} \mathrm{O}_{2}$ and metformin, or culture medium alone, and then incubated for $24 \mathrm{~h}$. Subsequently, labeling of apoptotic cells in the samples was performed using a TUNEL kit (ApopTag; Millipore, Billerica, MA, USA), which involves modifying DNA fragments by utilizing terminal deoxynucleotidyl transferase. Specific staining allowed for the detection of apoptotic cells.

Statistical analysis. All samples were run at least in triplicate. A one-way analysis of variance was used when multiple comparisons were made. The significance between two groups was determined using Tukey's test. Data are expressed as the mean \pm standard error. $\mathrm{P}<0.05$ was considered to indicate a statistically significant difference.

\section{Results}

MTT assay. Metformin at concentrations $\geq 5 \mathrm{mM}$ significantly reduced cell viability compared with that of the control group at $24 \mathrm{~h}$ after treatment (Fig. 1A). Metformin concentrations of 10,50 and $100 \mathrm{mM}$ reduced the cell viability from $100 \pm 1.6$ to $76.8 \pm 3.3,31.8 \pm 5.3$ and $16.7 \pm 0.7 \%$, respectively. Similar results were observed in the presence of $2.5 \mathrm{mM} \mathrm{H}_{2} \mathrm{O}_{2} . \mathrm{H}_{2} \mathrm{O}_{2}$ reduced the viability of the cells by $\sim 50 \%$. In the presence of $2.5 \mathrm{mM}$ $\mathrm{H}_{2} \mathrm{O}_{2}$, metformin reduced the cell viability compared with that 
A

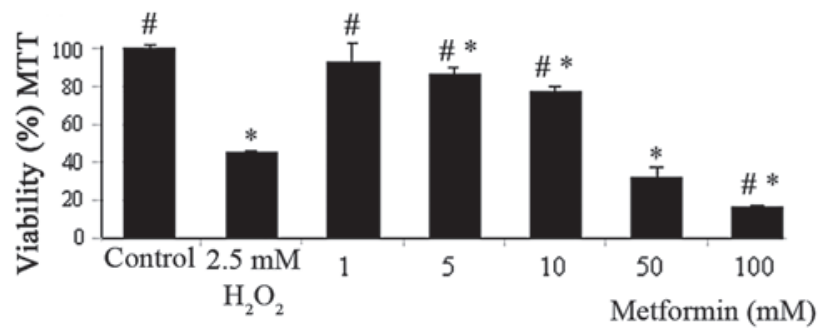

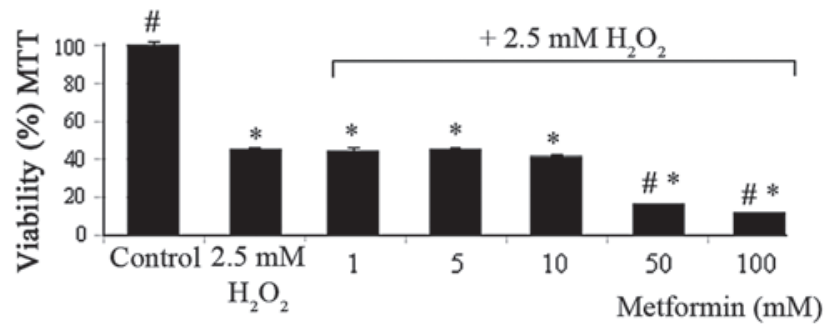

Figure 1. MTT assay viability results in T98G cells. Viability of the T98G cells in the 24 h presence of (A) metformin (1, 5, 10, 50 and $100 \mathrm{mM})$ and (B) metformin $(1,5,10,50$ and $100 \mathrm{mM})+2.5 \mathrm{mM} \mathrm{H}_{2} \mathrm{O}_{2}$ combination. All data are expressed as the mean and $\mathrm{SE}$ from three independent experiments. "P $<0.001$ vs. control, ${ }^{"} \mathrm{P}<0.001$ vs. $2.5 \mathrm{mM} \mathrm{H}_{2} \mathrm{O}_{2}$. MTT, 3-(4,5-dimethylthiazol-2-yl)-2,5-diphenyltetrazolium bromide.

A

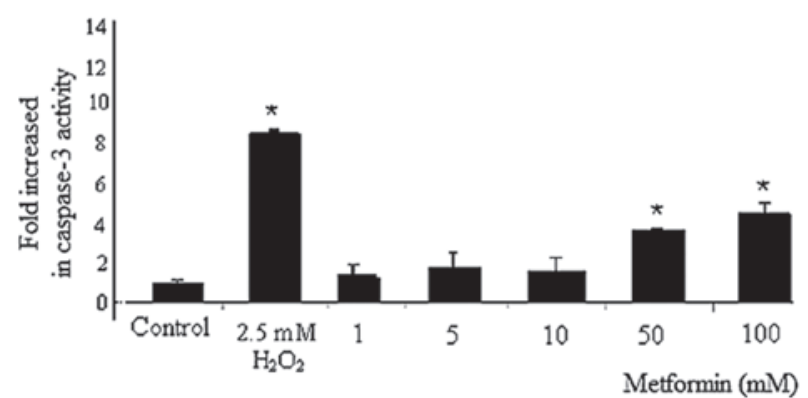

B

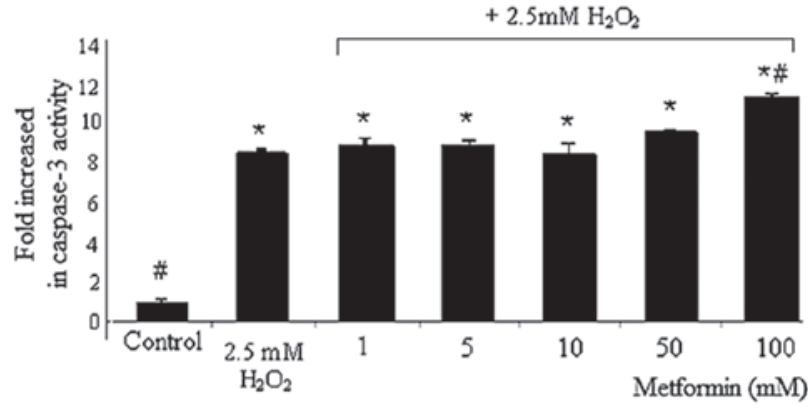

Figure 2. Fold increase in caspase 3 activity in T98G cells. (A) Metformin (1, 5, 10, 50 and $100 \mathrm{mM})$ and (B) metformin (1, 5, 10, 50 and 100 mM) $+2.5 \mathrm{mM}$ $\mathrm{H}_{2} \mathrm{O}_{2}$ combination. All data are expressed as the mean and $\mathrm{SE}$ from three independent experiments. ${ }^{*} \mathrm{P}<0.001$ vs. control, ${ }^{\#} \mathrm{P}<0.001$ vs. $2.5 \mathrm{mM} \mathrm{H}_{2} \mathrm{O}_{2}$.

of the control group at concentrations $\geq 1 \mathrm{mM}$. This reduction was significant at metformin concentrations of 50 and $100 \mathrm{mM}$ compared with the reduction caused by $2.5 \mathrm{mM} \mathrm{H}_{2} \mathrm{O}_{2}$ alone (Fig. 1B).

Caspase-3 assay. Compared with the caspase-3 levels in the control cells, metformin treatment increased caspase-3 levels significantly at 50 and $100 \mathrm{mM}$, from $1 \pm 0.20$ to $3.7 \pm 0.1$ and $4.9 \pm 0.6 \%$, respectively. However, $2.5 \mathrm{mM} \mathrm{H}_{2} \mathrm{O}_{2}$ alone also caused a significant increase in the caspase-3 levels compared with those in the control group (from $1 \pm 0.20$ to $8.67 \pm 0.18 \%$ ). In the presence of $2.5 \mathrm{mM} \mathrm{H}_{2} \mathrm{O}_{2}$, metformin at $1,5,10,50$ and $100 \mathrm{mM}$ increased the levels of caspase- 3 from $1 \pm 0.20$ to $9 \pm 0.4,9 \pm 0.2,8.6 \pm 0.5,9.7 \pm 0.1$ and $11.5 \pm 0.2 \%$, respectively, compared with those in the control group. Additionally, $100 \mathrm{mM}$ metformin $+2.5 \mathrm{mM} \mathrm{H}_{2} \mathrm{O}_{2}$ significantly increased the levels of caspase-3 activity compared with those in the $2.5 \mathrm{mM} \mathrm{H}_{2} \mathrm{O}_{2}$ group $(11.5 \pm 0.2$ vs. $8.67 \pm 0.18 \%$, respectively; Fig. 2).

Acridine orange and ethidium bromide staining. Apoptotic cells were not observed in the control group. However, apoptotic changes were observed in the presence of 10 , 50 and $100 \mathrm{mM}$ metformin and these changes increased as the concentration of metformin increased. Apoptotic changes were also observed following treatment with $2.5 \mathrm{mM} \mathrm{H}_{2} \mathrm{O}_{2}$ alone and with all concentrations of metformin in the presence of $2.5 \mathrm{mM} \mathrm{H}_{2} \mathrm{O}_{2}$. Apoptotic cells are marked with arrows in Fig. 3.
TUNEL assay. Incorporation of the TUNEL dye into apoptotic cells was assessed $24 \mathrm{~h}$ after treatment. Metformin induced apoptotic changes in the 50 and $100 \mathrm{mM}$ groups. Apoptosis-specific morphological changes were observed in the presence of $2.5 \mathrm{mM} \mathrm{H} \mathrm{O}_{2}$ alone and with all concentrations of metformin. Apoptotic cells are marked with arrows in Fig. 4.

\section{Discussion}

Glioblastoma is the most common and aggressive primary brain tumor of the human central nervous system. The median survival time is approximately one year for patients with advanced tumors. Despite intensive efforts to identify more effective therapies against glioblastoma, the possibility of successful treatment is extremely poor. New approaches have demonstrated that the induction of apoptosis in malignant cells may be a promising strategy in cancer therapy (18). Furthermore, metformin easily crosses the blood-brain barrier (17). In the present study, the effectiveness of metformin as an antiglioma agent was investigated from this perspective. The results show that metformin exerted apoptotic and antiproliferative effects in a concentration-dependent manner, and that these effects were increased in the presence of $\mathrm{H}_{2} \mathrm{O}_{2}$.

In the present study, it was determined using an MTT assay that metformin inhibited the proliferation of the T98G cells, and that the effect was more pronounced following the addition of $\mathrm{H}_{2} \mathrm{O}_{2}$. This effect occurred in a concentration-dependent 

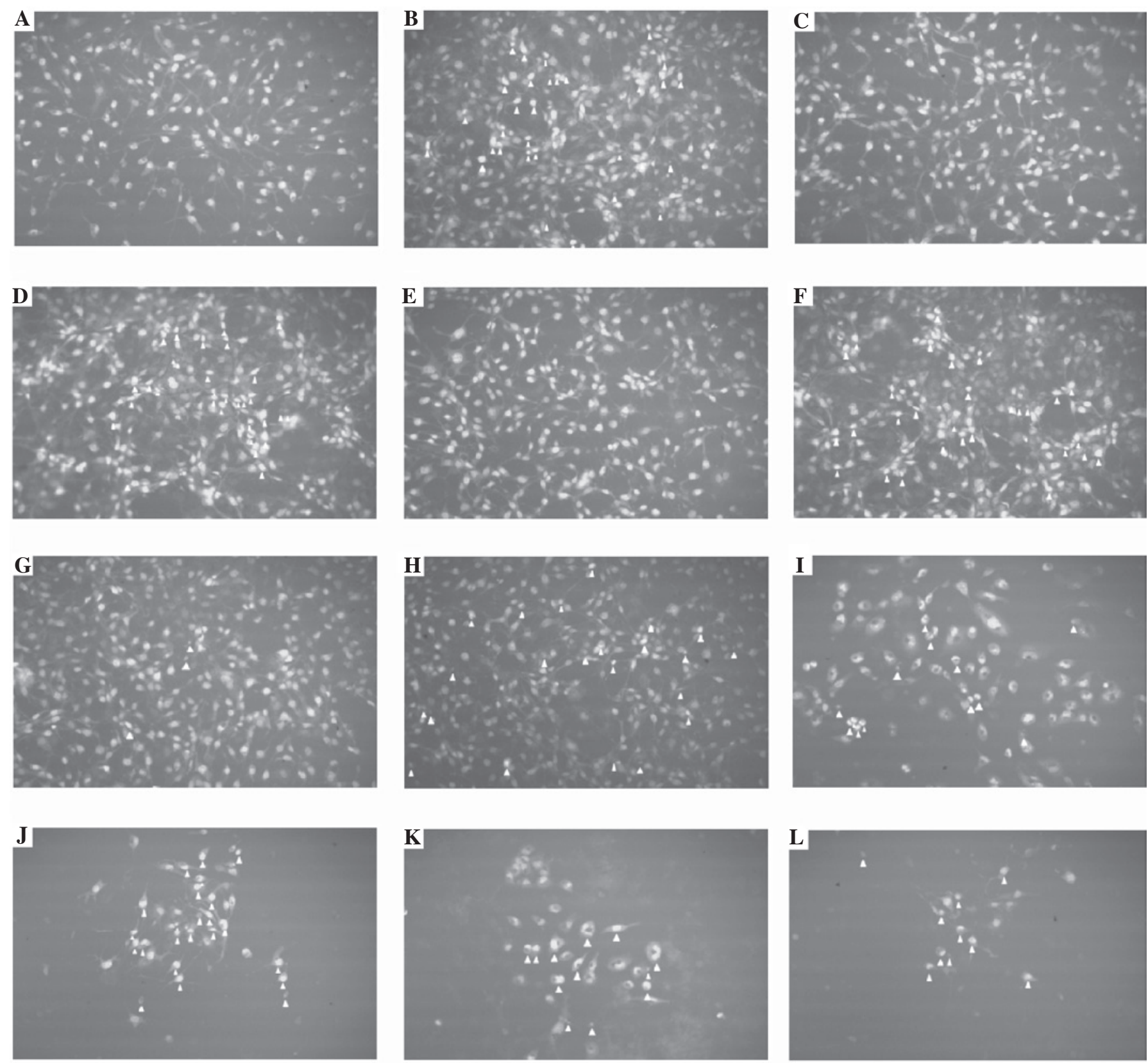

Figure 3. Ethidium bromide and acridine orange fluorescein dye in the T98G cell line (magnification $\mathrm{x} 400$ ). Apoptotic cells are indicated with an arrowhead (A) Control, (B) $2.5 \mathrm{mM} \mathrm{H}_{2} \mathrm{O}_{2}$, (C) $1 \mathrm{mM}$ metformin, (D) $1 \mathrm{mM}$ metformin $+2.5 \mathrm{mM} \mathrm{H}_{2} \mathrm{O}_{2}$, (E) $5 \mathrm{mM}$ metformin, (F) $5 \mathrm{mM} \mathrm{metformin}+2.5 \mathrm{mM} \mathrm{H} \mathrm{O}_{2}$, (G) $10 \mathrm{mM}$ metformin, (H) $10 \mathrm{mM}$ metformin $+2.5 \mathrm{mM} \mathrm{H}_{2} \mathrm{O}_{2}$, (I) $50 \mathrm{mM}$ metformin, (J) $50 \mathrm{mM}$ metformin $+2.5 \mathrm{mM} \mathrm{H}{ }_{2} \mathrm{O}_{2}$, (K) $100 \mathrm{mM}$ metformin, (L) $100 \mathrm{mM}$ metformin $+2.5 \mathrm{mM} \mathrm{H}_{2} \mathrm{O}_{2}$.

manner for 1-100 mM metformin. However, it was not possible to use this method to determine how the cells died (19). Thus, different assays were used to determine whether metformin exerts an apoptotic effect.

The nuclear morphology and light emission rates of the T98G cells were evaluated by staining with acridine orange and ethidium bromide. The data showed that apoptotic changes occurred in the cells following treatment with 10,50 and $100 \mathrm{mM}$ metformin and $\geq 1 \mathrm{mM}$ metformin in the presence of $\mathrm{H}_{2} \mathrm{O}_{2}$. However, throughout the experiments, cell washing and transfers may have changed the cell population distribution and apoptotic and/or necrotic cell rates (20). The TUNEL and caspase-3 assays in the present study produced similar results for $\geq 50 \mathrm{mM}$ metformin when used alone. However, as shown in a previous study, metformin-induced cell apoptosis may occur in a caspase-independent manner (7). In the present study, the effects of metformin on apoptosis were observed in the presence of $\mathrm{H}_{2} \mathrm{O}_{2}$. The results indicate that the apoptotic effect of metformin was increased when it was applied in combination with $\mathrm{H}_{2} \mathrm{O}_{2}$.

The combination of metformin with cytotoxic drugs has been shown to markedly inhibit tumor growth $(21,22)$. In this respect, metformin is used as an adjunct to cancer chemotherapy $(23,24)$. However, metformin has been demonstrated 

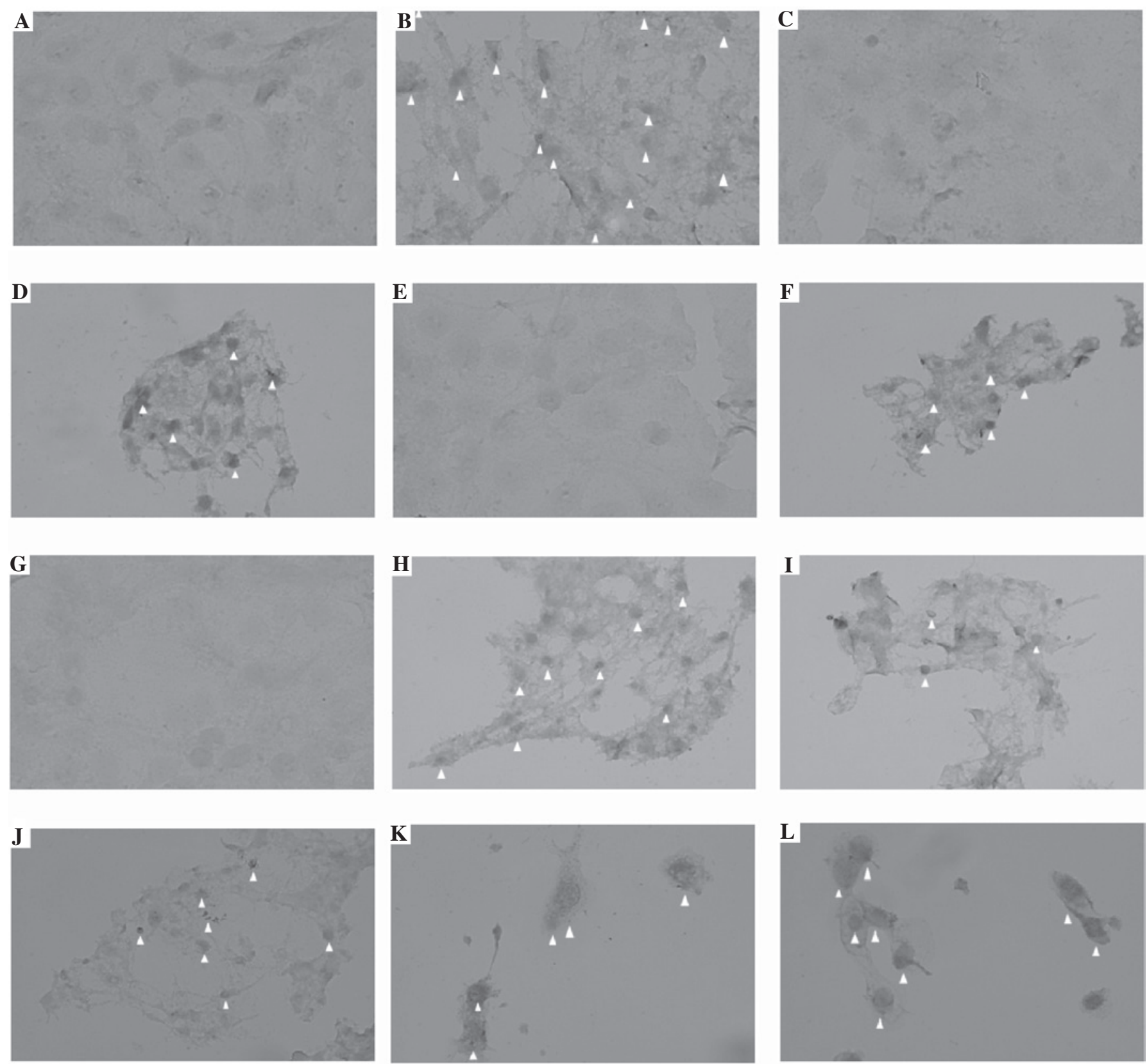

Figure 4. Apoptosis by TUNEL assay of the T98G cell line (magnification $\mathrm{x} 400$ ). Apoptotic cells are indicated with an arrowhead. (A) Control, (B) $2.5 \mathrm{mM}$

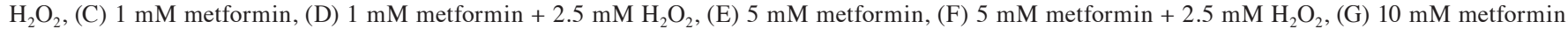
(H) $10 \mathrm{mM}$ metformin $+2.5 \mathrm{mM} \mathrm{H}_{2} \mathrm{O}_{2}$, (I) $50 \mathrm{mM}$ metformin, (J) $50 \mathrm{mM}$ metformin $+2.5 \mathrm{mM} \mathrm{H}_{2} \mathrm{O}_{2}$, (K) $100 \mathrm{mM}$ metformin, (L) $100 \mathrm{mM} \mathrm{metformin} \mathrm{+} 2.5 \mathrm{mM}$ $\mathrm{H}_{2} \mathrm{O}_{2}$. TUNEL, terminal deoxynucleotidyl transferase dUTP nick end labeling.

to suppress cisplatin-induced apoptosis in cancer cells (25). Although it has been demonstrated in other cell lines, few studies in the literature have reported the apoptotic effect of metformin on glioblastoma cells $(26,27)$. Epithelial growth factor receptor (EGFR) in connection with the phosphoinositol-3 kinase (PI3K) pathway signaling, as well as the association between the EGFR and the mTOR signaling pathway, appears important to maintaining the life of glioblastoma multiforme cells $(28,29)$. Therefore, PI3K and mTOR signaling pathway inhibitors alone or in conjunction with EGFR have become a novel therapeutic target. Metformin as an mTOR inhibitor may provide an important contribution to the treatment of glioblastoma multiforme. The findings of the present study show the effect of metformin on T98G cells and may provide a novel perspective regarding the future treatment of glioblastoma multiforme.

We predict that the direction of future treatment for glioblastoma multiforme will be to optimize surgery to remove the tumor and to use multi-targeted synergistic drug combinations. The targets of the novel drugs are likely to be cell survival mechanisms and apoptosis. In this respect, the apoptotic property of metformin shown in the present study in T98G cells indicate that metformin may be a good candidate for inclusion in treatment protocols. 


\section{References}

1. Campbell IW: Metformin - life begins at 50: A symposium held on the occasion of the 43rd Annual Meeting of the European Association for the Study of Diabetes, Amsterdam, The Netherlands, September 2007. (Meeting Report). Br J Diabet Vasc Dis 7: 247-252, 2007.

2. Li J, Deng J, Sheng W and Zuo Z: Metformin attenuates Alzheimer's disease-like neuropathology in obese, leptin-resistant mice. Pharmacol Biochem Behav 101: 564-574, 2012.

3. Wahlqvist ML, Lee MS, Hsu CC, Chuang SY, Lee JT and Tsai HN: Metformin-inclusive sulfonylurea therapy reduces the risk of Parkinson's disease occurring with Type 2 diabetes in a Taiwanese population cohort. Parkinsonism Relat Disord 18 753-758, 2012.

4. Gallagher EJ and LeRoith D: Diabetes, cancer, and metformin: connections of metabolism and cell proliferation. Ann NY Acad Sci 1243: 54-68, 2011.

5. Libby G, Donnelly LA, Donnan PT, Alessi DR, Morris AD and Evans JM: New users of metformin are at low risk of incident cancer: a cohort study among people with type 2 diabetes. Diabetes Care 32: 1620-1625, 2009.

6. Evans JM, Donnelly LA, Emslie-Smith AM, Alessi DR and Morris AD: Metformin and reduced risk of cancer in diabetic patients. BMJ 330: 1304-1305, 2005.

7. Zhuang Y and Miskimins WK: Metformin induces both caspase-dependent and poly(ADP-ribose) polymerase-dependent cell death in breast cancer cells. Mol Cancer Res 9: 603-615, 2011.

8. Will MA, Palaniappan M, Peegel H, Kayampilly $\mathrm{P}$ and Menon KM: Metformin: direct inhibition of rat ovarian theca-interstitial cell proliferation. Fertil Steril 98: 207-214, 2012.

9. Colquhoun AJ, Venier NA, Vandersluis AD, Besla R, Sugar LM Kiss A, Fleshner NE, Pollak M, Klotz LH and Venkateswaran V: Metformin enhances the antiproliferative and apoptotic effect of bicalutamide in prostate cancer. Prostate Cancer Prostatic Dis 15: 346-352, 2012.

10. Zhou G, Myers R, Li Y, Chen Y, Shen X, Fenyk-Melody J, et al: Role of AMP-activated protein kinase in mechanism of metformin action. J Clin Invest 108: 1167-1174, 2001.

11. Shaw RJ, Lamia KA, Vasquez D, Koo SH, Bardeesy N, Depinho RA, Montminy M and Cantley LC: The kinase LKB1 mediates glucose homeostasis in liver and therapeutic effects of metformin. Science 310: 1642-1646, 2005.

12. Ben Sahra I, Regazzetti C, Robert G, Laurent K, Le Marchand-Brustel Y, Auberger P, Tanti JF, Giorgetti-Peraldi S and Bost F: Metformin, independent of AMPK, induces mTOR inhibition and cell-cycle arrest through REDD1. Cancer Res 71: 4366-4372, 2011.

13. Zhuang Y and Miskimins WK: Cell cycle arrest in Metformin treated breast cancer cells involves activation of AMPK, downregulation of cyclin D1, and requires p27Kip1 or p21Cip1. J Mol Signal 3: 18, 2008

14. Peacock KH and Lesser GJ: Current therapeutic approaches in patients with brain metastases. Curr Treat Options Oncol 7: 479-489, 2006
15. Zhou J, Atsina KB, Himes BT, Strohbehn GW and Saltzman WM: Novel delivery strategies for glioblastoma. Cancer J 18: 89-99, 2012.

16. Krakstad C and Chekenya M: Survival signalling and apoptosis resistance in glioblastomas: opportunities for targeted therapeutics. Mol Cancer 9: 135, 2010.

17. Łabuzek K, Suchy D, Gabryel B, Bielecka A, Liber S and Okopień B: Quantification of metformin by the HPLC method in brain regions, cerebrospinal fluid and plasma of rats treated with lipopolysaccharide. Pharmacol Rep 62: 956-965, 2010.

18. Ferreira CG, Epping M, Kruyt FA and Giaccone G: Apoptosis: target of cancer therapy. Clin Cancer Res 8: 2024-2034, 2002.

19. Twentyman PR and Luscombe M: A study of some variables in a tetrazolium dye (MTT) based assay for cell growth and chemosensitivity. Br J Cancer 56: 279-285, 1987.

20. Muppidi J, Porter M and Siegel RM. Measurement of apoptosis and other forms of cell death. Curr Protoc Immunol Chapter 3: Unit 3.17, 2004.

21. Ben Sahra I, Le Marchand-Brustel Y, Tanti JF and Bost F: Metformin in cancer therapy: a new perspective for an old antidiabetic drug? Mol Cancer Ther 9: 1092-1099, 2010.

22. Jalving M, Gietema JA, Lefrandt JD, de Jong S, Reyners AK, Gans RO and de Vries EG.: Metformin: taking away the candy for cancer? Eur J Cancer 46: 2369-2380, 2010.

23. Iliopoulos D, Hirsch HA and Struhl K: Metformin decreases the dose of chemotherapy for prolonging tumor remission in mouse xenografts involving multiple cancer cell types. Cancer Res 71: 3196-3201, 2010.

24. Janjetovic K, Vucicevic L, Misirkic M, Vilimanovich U, Tovilovic G, Zogovic N, et al: Metformin reduces cisplatin-mediated apoptotic death of cancer cells through AMPK-independent activation of AKT. Eur J Pharmacol 651: 41-50, 2011

25. Rattan R, Graham RP, Maguire JL, Giri S and Shridhar V: Metformin suppresses ovarian cancer growth and metastasis with enhancement of cisplatin cytotoxicity in vivo. Neoplasia 13: 483-491, 2011.

26. Isakovic A, Harhaji L, Stevanovic D, Markovic Z, Sumarac-Dumanovic M, Starcevic V, Micic D and Trajkovic V: Dual antiglioma action of metformin: cell cycle arrest and mitochondria-dependent apoptosis. Cell Mol Life Sci 64: 1290-1302, 2007.

27. Vucicevic L, Misirkic M, Janjetovic K, Harhaji-Trajkovic L, Prica M, Stevanovic D, Isenovic E, Sudar E, Sumarac-Dumanovic M, Micic D and Trajkovic V: AMP-activated protein kinase-dependent and -independent mechanisms underlying in vitro antiglioma action of compound C. Biochem Pharmacol 77: 1684-1693, 2009.

28. Kraskstad C and Chekenya M: Survival signalling and apoptosis resistance in glioblastomas: opportunities for targeted therapeutics. Mol Cancer 9: 135, 2010.

29. Mao H, Lebrun DG, Yang J, Zhu VF and Li M: Deregulated signaling pathways in glioblastoma multiforme: molecular mechanisms and therapeutic targets. Cancer Invest 30: 48-56, 2012. 